\title{
Unele consideraţii mai de aproape privind timpul de muncă la distanţă ${ }^{1}$
}

\section{Some Considerations From a Closer Look at Distance Working Time}

\section{Septimiu Panainte ${ }^{2}$}

\begin{abstract}
Rezumat: Digitalizarea accentuată a activităţilor în ultimii ani a determinat creşterea semnificativă a situaţiilor în care munca este prestată de la distanţă. Dincolo de potenţialele avantaje, se pot identifica şi o serie de riscuri, iar printre acestea se află şi aspectele care privesc evidenţa şi gestionarea timpului de muncă. Legea nr. 81/2018 privind reglementarea activităţii de telemuncă poate fi apreciată ca adecvată în multe privinţe. Totuşi, conţine şi aspecte perfectibile privind: riscul stabilirii de condiţii restrictive în regulamentele interne în raport de stabilirea programului de lucru şi de verificarea activităţii telesalariaţilor de către reprezentanţii organizaţiilor sindicale ori de către reprezentanţii salariaţilor, reglementările concrete privind evidenţa timpului de lucru (sunt insuficiente), protecţia împotriva fragmentării excesive a timpului de lucru, necesitatea asigurării unui just echilibru între viaţa profesională şi cea privată a telesalariatului, consacrarea dreptul la deconectare etc.
\end{abstract}

Cuvinte-cheie: munca la distanţă; digitalizare; timp de muncă; program de muncă; dreptul la deconectare

Abstract: The increased digitalization of activities in recent years has induced to a significant evolution of situations in which work is performed remotely. Beyond the benefits, a number of risks can be identified, and among them are the aspects regarding the evidence and management of working time. Law no. 81/2018 on telework activity is definitely adequate in many aspects. But, also, it contains issues that can be improved regarding: the risk of setting up restrictive conditions in the internal regulations concerning the establishment of the work schedule or the verification of the activity of teleworkers by union representatives, concrete regulations on working time records, protection against excessive fragmentation of working time, the fair balance between the professional and

${ }^{1}$ Acest studiu a fost realizat în acord cu liniile directoare ale proiectului fean Monnet Module on EU Interdisciplinary Studies: Widening Knowledge for a more Resilient Union EURES (621262-EPP-1-2020-1-RO-EPPJMO) implementat de către Centrul de Studii Europene (Centru de excelență Jean Monnet) din cadrul Facultății de Drept, Universitatea „Alexandru Ioan Cuza” din Iași.

${ }^{2}$ Conferențiar univ. dr., Facultatea de Drept, Universitatea „Alexandru Ioan Cuza” din Iaşi, e-mail: septimiu.panainte@uaic.ro. 
private life of the teleworker (is not enough taken into account), the right to disconnect (is not settled) etc.

Keywords: remote work; digitalization; working time; work schedule; right to disconnect

\section{Aspecte introductive}

Evoluţiile tehnologice şi digitalizarea accentuată a activităţilor în ultimii ani şi mai ales în perioada de pandemie au determinat dezvoltarea de forme din ce în ce mai eterogene de prestare a muncii, iar munca de la distanţă (în special telemunca, în sensul Legii nr. 81/2018 privind reglementarea activităţii de telemuncă ${ }^{3}$ ) este din ce în ce mai des întâlnită provocând şi atenţia doctrinei de specialitate $^{4}$.

Telemunca prezintă o serie de avantaje atât pentru salariat (reducerea sau eliminarea timpului de deplasare zilnic către locul de muncă, diminuarea riscului de îmbolnăvire în cazul bolilor contagioase, o mai mare autonomie şi flexibilitate în organizarea activităţii, o mai mare productivitate, posibilităţi mai mari de adaptare a activităţii profesionale la viaţa de familie etc.), cât şi pentru angajator (acesta poate beneficia de o posibilă creştere a motivaţiei salariaţilor şi de o eficienţă mai ridicată a muncii, de reducerea sau eliminarea completă a unor costuri etc.). Aceste avantaje sunt în marea lor majoritate potenţiale şi pot deveni realitate dacă sunt favorizate de reglementări adecvate şi de o abordare constructivă a părţilor la raporturile juridice de muncă (depind în mare măsură în special de

3 Publicată în M.Of. nr. 296 din 02 aprilie 2018. Prezentul studiu nu are în vedere munca la domiciliu, ca formă a muncii la distanță, în reglementarea acesteia prin dispozițiile art. 108-110 din Codul muncii.

${ }^{4}$ A se vedea, spre exemplu, M.-E. Marica, Contracte de muncă atipice, Editura Universul juridic, Bucureşti, 2019; A. Ștefănescu, Munca la domiciliu și telemunca. Drept intern și comparat, Editura Universul Juridic, Bucureşti, 2011; A, Cioriciu Ștefănescu, Telemunca, în R.R.D.M., nr. 1/2009, pp. 60-105; C.-A. Moarcăș, Efectele globalizării, transformarea relației de muncă și regândirea dialogului social, în RRDP, nr. 4/2019, Autonomia dreptului muncii, coordonatori A. Athanasiu, L. Dima, pp. 55-79; L. Dima, Aspecte de noutate privind mijloacele materiale de probă în contextul noilor tehnologii, în Conferința Internațională de Dreptul Muncii - Noile tehnologii, consecințe asupra raportului de muncă, Sibiu, 11-12 octombrie 2019, Editura Universul Juridic, 2020, pp. 59-70; M. Gheorghe, Munca prestată prin utilizarea platformelor digitale. Consecințe asupra principiului egalității de tratament, în Conferința Internațională de Dreptul Muncii - Noile tehnologii..., cit. supra, pp. 166-171; C.C. Nenu, Evoluția conceptului de securitate și sănătate în muncă în contextul noilor tehnologii, în Conferința Internațională de Dreptul Muncii Noile tehnologii..., cit. supra, pp. 118-123; S. Panainte, Considerații privind alienarea salariatului în industria 4.0., în Conferința Internațională de Dreptul Muncii - Noile tehnologii..., cit. supra, pp. 172-181; J.-M. Servais, Economia colaborativă a platformelor electronice: noi provocări, noi protecții, în Conferința Internațională de Dreptul Muncii - Noile tehnologii..., cit. supra, pp. 11-33; M. Țichindelean, Considerații privind protecția datelor cu caracter personal în raporturile de muncă prin utilizarea mijloacelor de supraveghere video, în Conferința Internațională de Dreptul Muncii - Noile tehnologii..., cit. supra, pp. 83-89. 
specificul activităţii şi de nivelul de elevare a managementului resurselor umane aplicat în practică).

În acelaşi timp însă, nu trebuie neglijate riscurile pe care le induce munca la distanţă în două planuri majore şi definitorii pentru relaţia de muncă: cel al sănătăţii şi securităţii în muncă şi cel al echilibrului dintre viaţa profesională şi viaţa privată a lucrătorului. Aceste riscuri sunt sublimate în practică prin predispoziţia la program prelungit şi efectuarea de ore suplimentare, creşterea sau diluarea intensităţii muncii, fragmentarea excesivă a programului de lucru, invadarea spaţiului privat prin activităţi de monitorizare a activităţii, expunerea unor date cu caracter personal, izolarea şi creşterea nivelului de stres profesional şi de oboseală, expunerea excesivă la radiaţiile de radiofrecvenţă, perceperea activităţii efectuate de la distanţă ca periferică şi riscul producerii unor acte de discriminare în special indirectă a telesalariaţilor, comparativ cu cei care desfăşoară activităţi la locurile de muncă organizate de către angajator în cadrul structurilor acestuia, dificultăţi de sindicalizare etc. În mod evident, în cazul decuplării activităţii salariatului de locul de muncă tradiţional şi plasării acesteia în special la domiciliu este amplificat riscul unei suprapuneri sau, după caz, unei interferențe mai acute între viaţa profesională şi cea privată, aspect care reclamă metode adecvate de echilibrare. ${ }^{5}$ Dintr-o altă perspectivă, munca la distanţă are potenţialul de a favoriza creşterea activităţilor pe bază de contracte cu elemente particulare sau chiar atipice, cum ar fi cele on call sau zero hours, cu toate vulnerabilităţile pe care acestea le presupun.

Pe acest fond, adoptarea Legii nr. 81/2018 privind reglementarea activităţii de telemuncă a semnificat asumarea de către legiuitor a scopului protectiv în raport de aspectele specifice telemuncii ${ }^{6}$, în mod special în planul sănătăţii şi securităţii în muncă a salariaţilor.

\section{Aspecte generale privind timpul de muncă la distanţă}

Aspectele privind timpul de muncă sunt în mod esenţial subsumate asigurării sănătăţii şi securităţii în muncă a salariaţilor, iar reglementarea timpului de muncă are foarte adesea ca scop principal sau secundar garantarea timpului de repaus necesar pentru refacerea capacităţii de muncă. De altfel, prin art. 1 alin. (1) din Directiva 2003/88/CE privind anumite aspecte ale organizării timpului de lucru

${ }^{5}$ Pentru detalii, a se vedea Raportul OIM, Ensuring decent working time for the future, International Labour Conference, 107th Session, 2018, General Survey concerning workingtime instruments, Geneva, 2018, Report of the Committee of Experts on the Application of Conventions and Recommendations (articles 19, 22 and 35 of the Constitution), Report III (Part B), [Online] la https://www.ilo.org/ilc/ILCSessions/previous-sessions/107/reports/ reports-to-the-conference/WCMS_618485/lang--en/index.htm, accesat 29.09.2021.

${ }^{6}$ Conform art. 2 lit. a, în sensul Legii nr. 81/2018, prin „telemuncă” se înțelege acea „formă de organizare a muncii prin care salariatul, în mod regulat și voluntar, își îndeplinește atribuțiile specifice funcției, ocupației sau meseriei pe care o deține în alt loc decât locul de muncă organizat de angajator, folosind tehnologia informației și comunicațiilor”. 
este stabilit că aceasta „stabileşte cerinţe minime de securitate şi sănătate pentru organizarea timpului de lucru”. Directiva nu reglementează expres aspecte privind timpul de muncă la distanţă.

Deşi adeseori criticată pentru caracterul incomplet sau nenuanţat al reglementării (din perspectiva abordării binare - timp de lucru şi de repaus), directiva a constituit un cadru referenţial pentru dezvoltarea unei jurisprudenţe bogate a CJUE care a dat consistenţă standardului de protecţie minimal necesar a fi avut în vedere de statele membre ${ }^{7}$.

Suplimentar, timpul de lucru şi de repaus trebuie privit prin prisma necesităţii asigurării unui just echilibru între viaţa profesională şi cea privată a telesalariatului. Dreptul intern nu tratează expres şi direct această perspectivă, iar reglementările dreptului european sunt limitate la acest moment la Directiva 2019/1158 privind echilibrul dintre viaţa profesională şi cea privată a părinţilor şi îngrijitorilor şi de abrogare a Directivei 2010/18/UE a Consiliului ${ }^{8}$.

În privinţa muncii la distanţă, aceasta a fost avută în vedere la adoptarea Directivei 2019/1152 privind transparenţa şi previzibilitatea condiţiilor de muncă

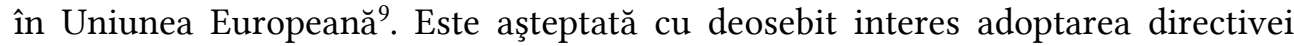
privind dreptul lucrătorilor de a se deconecta ${ }^{10}$.

În planul dreptului intern, reglementarea generală privind timpul de muncă şi timpul de odihnă este constituită de art. $111-158$ din Codul muncii, aplicabilă şi telemuncii în lipsa unor dispoziţii speciale derogatorii în Legea nr. 81/2018.

Timpul de muncă şi, implicit de repaus, este organic legat de alte elemente cum ar fi organizarea muncii, normarea muncii ${ }^{11}$, programul de lucru, evidenţa orelor lucrate ş.a. ${ }^{12}$

Impunerea acordului scris al telesalariatului cu normă întreagă pentru prestarea de muncă suplimentară este binevenită (art. 4 alin. (2) din Legea nr. 81/2018). Trebuie să înţelegem că este vorba de acordul prealabil şi special, vizând anumite ore suplimentare, clar individualizate. În lipsa unei dispoziţii derogatorii,

${ }^{7}$ De-a lungul timpului, CJUE a fost chemată să interpreteze prevederile directivei mai ales în considerarea unor situații particulare. Aspectele statuate de către Curte, inclusiv în unele cauze recent soluţionate, în special cu privire la delimitarea timp de muncă/timp de odihnă, sunt de natură să sublinieze necesitatea unor noi soluții de reglementare în acord cu o realitate economică și socială care a devenit deosebit de eterogenă și se află în proces de schimbare accelerată.

8 Publicată în JO L 188, 12.7.2019, p. 79-93.

${ }^{9}$ Publicată în JO L 186, 11.7.2019, p. 105-121.

${ }^{10}$ A se vedea Rezoluția Parlamentului European din 21 ianuarie 2021 conținând recomandări adresate Comisiei privind dreptul de a se deconecta (2019/2181(INL)), [Online] la https://www.europarl.europa.eu/doceo/document/TA-9-2021-0021_ RO.html, accesat 29.09.2021.

11 În alegerea legiuitorului român, norma de muncă este reglementată de Codul muncii în secțiune distinctă din cadrul capitolului dedicat timpului de muncă.

${ }^{12}$ Directiva 89/391 privind punerea în aplicare de măsuri pentru promovarea îmbunătățirii securității și sănătății lucrătorilor la locul de muncă (Directiva-cadru europeană privind securitatea și sănătatea în muncă). 
contractul cu timp parţial şi muncă la distanţă este posibil, în acest caz prestarea orelor suplimentare fiind interzisă ca urmare a aplicării regulii generale prevăzute de art. 105 alin. (1) lit. c) din Codul muncii.

O altă deosebire faţă de regimul comun al raporturilor de muncă priveşte faptul că, în cazul telemuncii, programul de lucru este organizat prin acordul părţilor, cu respectarea contextului normativ şi convenţional (art. 4 alin. (1) din Legea nr. 81/2018). În acest mod, în principiu, programul de lucru poate fi adaptat, inclusiv în privinţa fragmentării acestuia, la necesităţile şi dorinţele salariaţilor care ţin de viaţa privată a acestora.

Conform art. 5 alin. (2) lit. d) şi e) din Legea nr. 81/2018, în cazul activităţii de telemuncă trebuie avute în vedere, suplimentar faţă de elementele de conţinut ale obligaţiei de informare prevăzute la art. 17 alin. (3) din Codul muncii: programul în cadrul căruia angajatorul este în drept să verifice activitatea telesalariatului şi modalitatea concretă de realizare a controlului; modalitatea de evidenţiere a orelor de muncă prestate de telesalariat. Aceste elemente specifice au dimensiune convenţională şi trebuie să se regăsească şi în conţinutul înscrisului contractual/actului adiţional, după caz.

Faţă de cele de mai sus, considerăm că, pentru rigoare, şi programul de lucru trebuia inclus printre elementele de conţinut ale obligaţiei de informare specifice telemuncii.

\section{Observaţii şi aprecieri critice privind reglementarea timpului de muncă la distanţă}

3.1. Atât timp cât munca este desfăşurată de la distanţă prin utilizarea tehnologiilor de comunicare moderne, acestea asigurând mobilitatea lucrătorului, interesul angajatorului pentru a solicita prestarea activităţii într-un anumit loc (oricum în afara perimetrului organizat de către acesta) este minimal, uneori fiind chiar contraindicat acest lucru. Cel mai adesea, având în vedere potenţialele avantaje pentru îmbunătăţirea echilibrului între viaţa profesională şi cea privată a telesalariatului, dar şi restricţiile impuse pe fond pandemic, activitatea se desfăşoară de la domiciliul acestuia (în sens larg) ${ }^{13}$.

${ }^{13}$ Art. 5 alin. (2) lit. c) din Legea nr. 81/2018, privind menționarea în contractul de muncă a locului sau locurilor din care se desfășoară activitatea de telemuncă, a fost abrogat prin art. II pct. 3 din OUG nr. 36/2021 privind utilizarea semnăturii electronice în domeniul relațiilor de muncă și pentru modificarea și completarea unor acte normative, publicată în M.Of. nr. 474 din 06.05.2021, aprobată cu modificări și completări prin Legea nr. 208/2021. Resortul acestei abrogări ar putea fi acela că textul era de prisos în condițiile în care art. 17 alin. (3) lit. b) coroborat cu alin. (4) din Codul muncii prevede oricum obligația de informare și menționarea în contractul de muncă a locului de muncă sau, în lipsa unui loc de muncă fix, a posibilității ca salariatul să muncească în diverse locuri. Având în vedere specificul telemuncii, abrogarea ar putea avea ca semnificație și faptul că locul concret al muncii de la distanță nu este, ca regulă, determinant din perspectiva formării și scopului contractului, putând fi lăsat chiar la latitudinea salariatului (în mod evident însă, din perspectiva îndeplinirii obligațiilor specifice privind sănătatea și securitatea în muncă de către 
3.2. Reţinând acest aspect, devine evident că programul de lucru capătă o importanţă deosebită. De altfel, acest aspect poate fi sesizat şi din prioritatea în reglementare (art. 4 din lege). Se impun o serie de observaţii.

În primul rând, în formularea art. 4 alin. (1) din lege, „telesalariaţii organizează programul de lucru de comun acord cu angajatorul". Considerăm că în mod corect legiuitorul nu a apelat la soluţia corespondentă consacrată de Codul muncii în cazul contractului cu munca la domiciliu ${ }^{14}$. Din perspectiva reglementării, cele două forme de muncă la distanţă presupun premise sensibil diferite.

În sensul Acordului-cadru european privind telemunca din $2002^{15}$, telesalariaţii îşi pot gestiona singuri timpul de muncă, cu respectarea dispoziţiilor legale, contractelor colective de muncă şi regulilor adoptate la nivelul angajatorilor (pct. 9). Această opţiune are ca efect direct maximum de flexibilitate, iar indirect, probabil, un mai bun echilibru între viaţa privată şi cea profesională a telesalariaţilor, dar şi riscul desubstanţializării unor norme protective pentru salariat.

$\mathrm{O}$ atare opţiune de reglementare presupune în mod necesar şi responsabilizarea salariaţilor printr-o serie de reguli complementare. Ca premisă, din moment ce angajatorul nu are control asupra deciziei telesalariatului de organizare a timpului de muncă, nici nu va putea fi obligat suplimentar ca urmare a deciziei unilaterale a cocontractantului. Pe cale de consecinţă, „preţul” pentru a beneficia de maximum de flexibilitate poate fi faptul că telesalariaţii nu ar putea solicita plata de sporuri pentru ore suplimentare, muncă de noapte sau in perioadele de repaus (sens în care au fost date ca exemplu reglementările din Cehia şi Slovacia), sau, în general, de nici un fel de beneficiu suplimentar de timp liber sau financiar care ar putea rezulta din prestarea muncii în afara programului

angajator și al verificărilor posibile, inclusiv și mai ales când este la domiciliul salariatului, locul muncii este relevant). Și Directiva (UE) 2019/1152 privind transparența şi previzibilitatea condițiilor de muncă în Uniunea Europeană prevede printre elementele care fac obiectul obligației de informare „locul de desfășurare a activității; dacă nu există un loc de desfășurare a activității fix sau principal, principiul conform căruia lucrătorul are diverse locuri de desfășurare a activității sau este liber să își stabilească propriul loc de desfășurare a activității” (art. 4 alin. (2) lit. b).

${ }^{14}$ Art. 108 alin. (2) din Codul muncii: „În vederea îndeplinirii sarcinilor de serviciu ce le revin, salariaţii cu munca la domiciliu își stabilesc singuri programul de lucru”. Pentru telemuncă această soluție ar fi fost nerealistă, mai ales în condițiile actuale. Spre deosebire, legiuitorul a dovedit consecvență din perspectiva impunerii ca programul în cadrul căruia angajatorul este în drept să verifice activitatea salariatului şi modalitatea concretă de realizare a controlului să facă obiectul acordului de voință a părților și să fie menționate în contract (art. 109 lit. b) din Codul muncii, art. 5 alin. (2) lit. d) din Legea nr. 81/2018).

15 [Online] la https://resourcecentre.etuc.org/sites/default/files/2020-09/Telework\%202 002_Framework\%20 Agreement\%20-\%20EN.pdf, accesat 29.09.2021. 
normal de muncă (în acest sens fiind dat ca exemplu contractul colectiv pentru sectorul serviciilor financiare din Danemarca) ${ }^{16}$.

Revenind la soluţia consacrată de legea română, din moment ce angajatorul îşi exprimă acordul cu privire la modul de organizare a programului de lucru propus de telesalariat, îşi asumă şi toate consecinţele juridice pentru situaţii de tipul celor expuse mai sus. În acest fel, normele protective în materie de timp de muncă şi de repaus îşi pot atinge finalitatea.

În al doilea rând, remarcăm faptul că Legea nr. 81/2018 nu impune expres ca acordul părţilor în privinţa programului de lucru să aibă formă scrisă. Această condiţie privind forma nu poate fi dedusă nici din faptul că acest acord trebuie realizat „în conformitate cu prevederile contractului individual de muncă, regulamentului intern şi/sau contractului colectiv de muncă aplicabil, în condiţiile legii”. Considerăm că această soluţie de reglementare este de natură să faciliteze o oarecare variabilitate sau volatilitate a programului de lucru şi să conducă la probleme în planul capacităţii de a se dovedi anumite aspecte, fie în faţa inspectorilor de muncă, fie în faţa instanţei de judecată. Chiar dacă angajatorul trebuie să îşi îndeplinească obligaţia de a ţine evidenţa muncii prestate în modalitatea agreată cu telesalariatul, considerăm că se diminuează efectul pozitiv al impunerii formei scrise a acordului pentru efectuarea orelor suplimentare. Totodată, lipsa unui înscris probator pentru programul de lucru poate genera probleme şi în alte planuri: din perspectiva calificării muncii de noapte sau necesităţii verificării respectării timpului de repaus exprimat în ore consecutive; în cercetarea disciplinară, spre exemplu când se analizează eventuale absenţe nemotivate de la program etc. Mai apreciem că numai dacă programul de lucru este cunoscut în mod exact, fiind susceptibil de a fi comunicat doar de o parte a contractului, reprezentanţii organizaţiilor sindicale la nivel de unitate ori reprezentanţii salariaţilor sau inspectorii de muncă vor putea proceda în mod eficient la verificările instituite în competenţa lor conform art. 9 din lege.

Aşadar, punând în balanţă avantajul flexibilităţii şi riscurile de mai sus, apreciem că se impune completarea art. 4 din lege în sensul impunerii acordului în formă scrisă $\breve{~}^{17}$.

În al treilea rând, observăm că acordul părţilor privind organizarea programului de lucru se poate realiza ,în conformitate cu prevederile contractului individual de muncă, regulamentului intern şi/sau contractului colectiv de muncă aplicabil, în condiţiile legii”. Această enumerare, de altfel recurentă în cuprinsul

${ }^{16}$ A se vedea Raportul Eurofound Telework in the European Union, publicat la 10.01.2010, [Online] la https://www.eurofound.europa.eu/bg/publications/report/2010/telework-inthe-european-union, p. 17, accesat 29.09.2021.

${ }^{17} \mathrm{La}$ par. 31 din preambulul Directivei (UE) 2019/1152 privind transparența și previzibilitatea condițiilor de muncă în UE se menționează: „Orele și zilele de referință, care se interpretează ca fiind intervalele orare în care poate fi prestată munca la solicitarea angajatorului, ar trebui să fie stabilite în scris la începutul raportului de muncă”. Și o eventuală reglementare a dreptului la deconectare este condiționată de certitudinea programului de lucru și de posibilitățile salariatului de a îl dovedi în caz de conflict. 
Legii nr. 81/2018, priveşte premisele şi limitele în care părţile îşi pot exprima voinţa şi este criticabilă.

Astfel, alăturarea celor trei categorii de acte, diferite prin modul de formare şi scopuri, precum şi ordinea enumerării acestora, par mai degrabă aleatorii.

Contractul individual de muncă exprimă voinţa părţilor, în condiţiile legii şi ţinând cont de prevederile contractului colectiv de muncă, întocmai ca şi acordul privind programul de lucru. Dincolo de potenţiala asimetrie de formă, un acord ulterior încheierii contractului individual poate modifica şi modifică acel contract şi nu poate fi ţinut de prevederile iniţiale care eventual se intenţionează a fi modificate. Reglementarea se poate justifica într-o oarecare măsură în situaţia în care contractul individual nu prevede anumite aspecte şi se impune a fi completat ţinându-se cont de anumite repere determinante sau circumstanţiale conţinute în înscrisul contractual. E.g., stabilirea programului de lucru trebuie convenită în raport de felul muncii prevăzut în contract şi, eventual, de poziţia executivă sau managerială în structura organizaţională a angajatorului. Această interpretare fundamentată pe raţionamentul determinării limitelor în care se poate stabili programul de lucru prin alte elemente extrinseci acestuia ar putea fi primită şi cu privire la referirea la contractul colectiv de muncă.

Mai greu asimilabilă este însă trimiterea la regulamentul intern. Acesta este adoptat de către angajator, doar în baza consultării sindicatului sau a reprezentanţilor salariaţilor, după caz, şi nu în baza acordului acestora (art. 241 din Codul muncii). Aşadar, există riscul stipulării unilaterale în regulamentul intern a unor condiţii legale, dar restrictive în privinţa programului de lucru, aspect care poate conduce la limitarea libertăţii de voinţă a telesalariatului de către angajator.

Enumerarea analizată mai apare criticabilă prin prisma faptului că, pentru situaţia unui concurs, nu prioritizează în privinţa izvoarelor condiţiilor în care se poate stabili programul de lucru prin acordul părţilor. Din această perspectivă, pentru situaţia în care aceste condiţii ar fi tratate simultan diferit în surse distincte, s-ar putea urma soluţia de reglementare oferită de art. 63 alin. (2) din Codul muncii (prin care se acordă prioritate contractului colectiv de muncă în faţa regulamentului intern).

În al patrulea rând, Legea nr. 81/2018 nu conferă expres programului de lucru relevanţă în contextul reglementării verificărilor care pot interveni în cazul telemuncii, respectiv:

a) verificarea activităţii telesalariatului de către angajator. Conform art. 5 alin. (2) lit. d) din Legea nr. 81/2018, programul în cadrul căruia angajatorul este în drept să verifice activitatea telesalariatului şi modalitatea concretă de realizare a controlului trebuie să se regăsească în înscrisul contractual sau act adiţional; verificarea activităţii se realizează ,în principal prin utilizarea tehnologiei informaţiei şi comunicaţiilor, în condiţiile stabilite prin contractul individual de 
muncă, regulamentul intern şi/sau contractul colectiv de muncă aplicabil, în condiţiile legii” (art. 4 alin. (3) din Legea nr. 81/2018). ${ }^{18}$

b) verificarea condiţiilor de muncă ale telesalariatului de către reprezentanţii organizaţiilor sindicale la nivel de unitate ori reprezentanţii salariaţilor. În temeiul alin. (1) al art. 9 din Legea nr. 81/2018, pentru aplicarea şi verificarea condiţiilor de muncă ale telesalariatului, reprezentanţii organizaţiilor sindicale la nivel de unitate ori reprezentanţii salariaţilor au acces la locurile de desfăşurare a activităţii de telemuncă, ,în condiţiile stipulate în contractul colectiv de muncă sau contractul individual de muncă ori regulamentul intern, după caz"19.

c) verificarea aplicării şi respectării cerinţelor legale din domeniul securităţii şi sănătăţii în muncă şi al relaţiilor de muncă de către reprezentanţii autorităţilor competente: conform alin. (2) al art. 9, pentru a realiza activităţile de control reprezentanţii autorităţilor au dreptul de acces la locurile de desfăşurare a activităţii de telemuncă, în condiţiile stipulate în Legea nr. 108/1999 pentru înfiinţarea şi organizarea Inspecţiei Muncii.

Doar pentru ipoteza în care locul de desfăşurare a activităţii telesalariatului este la domiciliul acestuia (în sens larg), dreptul de acces pentru verificarea condiţiilor de muncă, respectiv respectării cerinţelor legale din domeniul securităţii şi sănătăţii în muncă, este condiţionat de notificarea prealabilă a telesalariatului şi de exprimarea consimţământului acestuia (art. 9 alin. 3$)^{20}$. Pentru accesul în domiciliu, acordul salariatului trebuie să fie prealabil şi special. Prin urmare, în acest caz, nu se poate vorbi de o verificare inopinată cu scop de surprindere a realităţii respectării de către salariat a condiţiilor de desfăşurare a activităţii.

După cum am arătat, programul în cadrul căruia angajatorul este în drept să verifice activitatea telesalariatului şi modalitatea concretă de realizare a controlului trebuie prevăzute în contractul de muncă sau în act adiţional la acesta. Pentru situaţia în care activitatea se desfăşoară la domiciliul salariatului Legea nr. 81/2018 nu impune expres consimţământul expres şi prealabil al acestuia, raportat la fiecare act de control, oricare ar fi modalitatea de verificare agreată de părţi. Premisa de la care a plecat legiuitorul a fost cea enunţată în art. 4 alin. 3 din lege, respectiv că verificarea activităţii se realizează ,în principal prin utilizarea tehnologiei informaţiei şi comunicaţiilor”, deci tot de la distanţă, fără a fi nevoie de verificare fizică sau detaliată în spaţiul în care salariatul prestează munca. Totuşi nu este exclus ca asemenea verificări să fie necesare şi convenite de părţi. Dacă munca este

${ }^{18}$ Şi cu privire la acest aspect se poate reține riscul subliniat mai sus ca prin regulamentul intern să fie impuse limite ale exprimării voinței salariatului.

${ }^{19}$ Regăsim aceeași disonanță: reprezentanții organizațiilor sindicale la nivel de unitate ori reprezentanții salariaților pot exercita un drept în condițiile stipulate în regulamentul intern adoptat de către angajator. Or, prin verificarea condițiilor de muncă ale telesalariatului, reprezentanții sindicatului sau salariaților verifică și dacă angajatorul și-a îndeplinit obligațiile aferente, nu numai dacă salariatul le respectă.

${ }^{20}$ Consimțământul salariatului este, fără îndoială, important prin prisma protecției dreptului la respectarea vieții private și de familie (în sensul art. 8 din CEDO și art. 26 și 27 din Constituția României). 
prestată de la domiciliul salariatului şi pentru verificările care revin autorităţilor statului se impune acordul expres al acestuia, cu atât mai mult acest acord este necesar în cazul verificărilor efectuate de către angajator. Altfel, ar exista riscul subordonării aspectelor care ţin de viaţa privată a salariatului şi membrilor familiei acestuia faţă de activitatea profesională - verificările domiciliare întreprinse de către angajator.

Mai avem în vedere faptul că activităţile de control presupun, în principiu, prezenţa sau cel puţin disponibilitatea de la distanţă a salariatului. Pe cale de consecinţă, în lumina jurisprudenţei $\mathrm{CJUE}^{21}$, intervalul în care se realizează sau se poate realiza controlul constituie perioadă în care salariatul, chiar dacă nu ar presta în mod efectiv activitate, se află într-o formă de exercitare a funcţiei sale şi, drept urmare, acest interval trebuie calificat ca fiind timp de muncă în sensul art. 2 pct. 1 din Directiva 88/2003.

Aşadar, dacă munca este prestată de la domiciliu, apreciem că, pentru a nu fi intruzive, toate activităţile de control sunt condiţionate de exprimarea consimţământului salariatului ${ }^{22}$ şi trebuie realizate în timpul programului de lucru. Pentru ipoteza în care activitatea nu se desfăşoară de la domiciliu, ci în alt loc agreat de părţi sau lăsat la alegerea telesalariatului, apreciem că acestea trebuie realizate, de asemenea, în timpul şi cu respectarea programului de lucru.

3.3. Un alt aspect specific muncii la distanţă, care este de natură să ridice probleme de ordin practic, este cel privind evidenţa orelor de muncă prestate zilnic de către telesalariat.

La nivel general, CJUE a statuat în cauza C-55/18 că normele europene impun statelor naţionale obligaţia de a impune angajatorilor instituirea unui sistem care să permită măsurarea duratei timpului de lucru zilnic efectuat de fiecare lucrător ${ }^{23}$.

${ }^{21}$ A se vedea, spre exemplu, cauza Ville de Nivelles vs. Rudy Matzak (C-518/15), par. 59 și jurisprudența citată.

${ }^{22}$ In acest sens este și pct. 8 din Acordul cadru european privind telemunca din 2002 (The European Framework Agreement on Telework) care se referă la notificarea prealabilă și la necesitatea consimțământului telesalariatului care prestează activități de la domiciliu pentru verificările efectuate de angajator, reprezentanții salariaţilor sau autorităţile competente în privința sănătății și securității în muncă (în măsura în care presupun accesul în domiciliu).

${ }^{23}$ Hotărârea CJUE (Marea Cameră) din 14 mai 2019, în cauza C-55/18, Federación de Servicios de Comisiones Obreras (CCOO) v. Deutsche Bank SAE: „Articolele 3, 5 și 6 din Directiva 2003/88/CE a Parlamentului European și a Consiliului din 4 noiembrie 2003 privind anumite aspecte ale organizării timpului de lucru, citite în lumina articolului 31 alineatul (2) din Carta drepturilor fundamentale a Uniunii Europene, precum şi a articolului 4 alineatul (1), a articolului 11 alineatul (3) și a articolului 16 alineatul (3) din Directiva 89/391/CEE a Consiliului din 12 iunie 1989 privind punerea în aplicare de măsuri pentru promovarea îmbunătățirii securității și sănătății lucrătorilor la locul de muncă, trebuie interpretate în sensul că se opun unei reglementări a unui stat membru care, potrivit interpretării care este dată acesteia de către jurisprudența naţională, nu impune angajatorilor obligația de a institui un sistem care să permită măsurarea duratei timpului de lucru zilnic efectuat de fiecare lucrător”. 
Codul muncii a reglementat încă din forma iniţială obligaţia angajatorilor de a ţine evidenta orelor de muncă prestate de fiecare salariat. În prezent, art. 119 din Cod prevede la alin. (1) obligaţia angajatorului „de a ţine la locul de muncă definit potrivit art. $16^{1}$ evidenţa orelor de muncă prestate zilnic de fiecare salariat, cu evidenţierea orelor de începere şi de sfârşit ale programului de lucru, şi de a supune controlului inspectorilor de muncă această evidenţă, ori de câte ori se solicită acest lucru”. Aşadar, ca regulă generală, îndatorirea de a ţine evidenţa activităţilor prestate revine angajatorului, acesta putând stabili în mod unilateral modalitatea concretă în care îşi îndeplineşte obligaţia.

Al doilea alineat al art. 119 tratează situaţia particulară a trei categorii de salariaţi (mobili, care desfăşoară muncă la domiciliu şi din cadrul microîntreprinderilor); pentru aceştia „angajatorul ţine evidenţa orelor de muncă prestate zilnic de fiecare salariat în condiţiile stabilite cu salariaţii prin acord scris, în funcţie de activitatea specifică desfăşurată de către aceştia”. La aceste categorii putem adăuga şi telesalariaţii, Legea nr. 81/2018 prevăzând la art. 5 alin. (2) lit. e) faptul că modalitatea de evidenţiere a orelor de muncă prestate de telesalariat trebuie să se regăsească în conţinutul contractului individual de muncă (deci are natură convenţională şi presupune exprimarea voinţei părţilor în scris). Raportat la aceste patru categorii de salariaţi, faptul că modalităţile şi condiţiile concrete de evidenţiere a muncii presupun acceptul acestora, nu semnifică faptul că obligaţia de a ţine evidenţa muncii nu rămâne exclusiv în sarcina angajatorului. Pentru a îşi îndeplini obligaţia, angajatorul va trebui să găsească o formula de evidenţiere adecvată, acceptabilă şi acceptată de salariaţii respectivi.

Dimensiunea convenţională a modalităţilor concrete de evidenţiere în cazul telesalariaţilor poate fi justificată prin necesitatea ca acestea să fie cunoscute de către aceştia, să fie adecvate naturii şi specificului activităţii şi prin perspectiva invocării în faţa organelor de control sau în faţa instanţelor de judecată a unor probe în consecinţă: înscrisuri (eventual electronice), mijloace materiale de probă etc.

În mod evident, în multe situaţii utilizarea tradiţionalei condici de prezenţă nu mai apare ca o soluţie viabilă. În cazul telesalariaţilor apare a fi adecvată şi, în consecinţă, mai probabilă, utilizarea unor aplicaţii informatice dedicate înregistrării timpului în care se prestează activitatea. Având în vedere că programele software utilizate pot avea funcţii complexe, trebuie delimitat între funcţia de contabilizare a timpului de muncă şi cea de monitorizare sau verificare a activităţii efectiv prestată de telesalariat ${ }^{24}$. Am arătat deja că şi modalitatea concretă de

${ }^{24}$ Pentru unele detalii a se vedea M. Samek Lodovici et al., The impact of teleworking and digital work on workers and society. Special focus on surveillance and monitoring, as well as on mental health of workers, 2021, publication for the Committee on Employment and Social Affairs, Policy Department for Economic, Scientific and Quality of Life Policies, European Parliament, [Online] la https:/op.europa.eu/en/publication-detail/-/publication/49c693a2cfdb-11eb-ac72-01aa75ed71a1/language-en, accesat 29.09.2021, și [Online] la http://www.europarl.europa.eu/supporting-analyses. 
realizare a controlului activităţii presupune acordul telesalariatului (art. 5 alin. (2) lit. d), independent de faptul că acesta lucrează de la domiciliu sau nu.

Mai trebuie adăugat că în cazul în care angajatorul intenţionează utilizarea unor sisteme de monitorizare prin mijloace de comunicaţii electronice şi/sau prin mijloace de supraveghere video la locul de muncă ${ }^{25}$ art. 5 din Legea nr. 190/2018 privind măsuri de punere în aplicare a Regulamentului (UE) 2016/679 al Parlamentului European şi al Consiliului din 27 aprilie 2016 privind protecţia persoanelor fizice în ceea ce priveşte prelucrarea datelor cu caracter personal şi privind libera circulaţie a acestor date şi de abrogare a Directivei 95/46/CE (Regulamentul general privind protecţia datelor) ${ }^{26}$ impune măsuri deosebit de stricte pentru prelucrarea datelor cu caracter personal ale salariaţilor. Astfel, dacă sunt utilizate asemenea sisteme de monitorizare, prelucrarea acestor date se poate realiza exclusiv în scopul realizării intereselor legitime urmărite de angajator şi este permisă numai dacă:

„a) interesele legitime urmărite de angajator sunt temeinic justificate şi prevalează asupra intereselor sau drepturilor şi libertăţilor persoanelor vizate;

b) angajatorul a realizat informarea prealabilă obligatorie, completă şi în mod explicit a angajaţilor;

c) angajatorul a consultat sindicatul sau, după caz, reprezentanţii angajaţilor înainte de introducerea sistemelor de monitorizare;

d) alte forme şi modalităţi mai puţin intruzive pentru atingerea scopului urmărit de angajator nu şi-au dovedit anterior eficienţa; şi

e) durata de stocare a datelor cu caracter personal este proporţională cu scopul prelucrării, dar nu mai mare de 30 de zile, cu excepţia situaţiilor expres reglementate de lege sau a cazurilor temeinic justificate”.

Faţă de caracterul imperativ al normei expuse, la nivel general, apreciem că, independent de locul desfăşurării activităţii, aceste condiţii nu sunt „negociabile” între salariaţi şi angajatori în considerarea dreptului persoanelor fizice de a dispune în privinţa datelor lor cu caracter personal. Se poate invoca, suplimentar, contextul executării contractului de muncă şi incidenţa art. 38 din Codul muncii.

Protecţia datelor cu caracter personal este însă cu atât mai necesară în condiţiile în care munca este îndeplinită de la distanţă şi mai ales când este prestată de la domiciliul telesalariatului folosind tehnologia informaţiei şi comunicaţiilor. În acest context, considerăm că acordul telesalariatului privind verificarea activităţii sale prin asemenea sisteme de monitorizare poate fi solicitat de către angajator numai după ce acesta s-a asigurat că sunt îndeplinite condiţiile impuse de art. 5 din Legea nr. 190/2018, citate mai sus. Aşadar, acordul salariatului în privinţa utilizării acestor sisteme nu poate implica şi nu se poate interpreta şi în sensul degrevării angajatorului de sarcina îndeplinirii condiţiilor impuse de lege.

25 A se vedea și Hotărârea CtEDO nr. 61496/08 din septembrie 2017, în cauza Bărbulescu contra României, [Online] la https://hudoc.echr.coe.int/eng\#\{\%22tabview\%22: [\%22 document\%22],\%22itemid \%22:[\%22001-180112\%22]\}.

26 Publicată în M.Of. 651 din 26.07.2018. 
Dacă angajatorul, verificând condiţia ca alte forme şi modalităţi mai puţin intruzive pentru atingerea scopului urmărit de angajator să nu îşi fi dovedit anterior eficienţa, nu are o altă alternativă în afara celei propuse telesalariatului şi acesta nu o acceptă, se va putea deduce că munca la distanţă nu este posibilă.

3.4. Organizarea programului de lucru la distanţă de către părţi de comun acord (art. 4 alin. (1)) prezintă potenţialul avantaj de a se agrea formule flexibile de lucru, reciproc avantajoase. Pe de altă parte, în condiţiile în care programul de lucru este subsumat în principal necesităţilor angajatorului şi/sau excesiv fragmentat, trebuie considerat riscul unor potenţiale efecte negative asupra echilibrului necesar între viaţa privată şi cea profesională a telesalariatului.

În acest context trebuie subliniat standardul minimal impus de Codul muncii în materie de repaus: cel puţin 12 ore consecutive între două zile de muncă (art. 135 alin. (1)) şi 48 de ore consecutive de repaus săptămânal, de regulă sâmbăta şi duminica (art. 137 alin. (1)) $)^{27}$.

În perspectivă, nu trebuie exclus ca şi durata maximă a timpului zilnic de lucru să fie reevaluată şi, eventual, redusă, având în vedere riscurile inerente pentru sănătatea salariaţilor pe care le atrage activitatea prelungită care presupune utilizarea computerelor.

3.5. Mai poate fi subliniat faptul că munca de la distanţă este de natură să conducă la creşterea raporturilor de muncă cu elemente de extraneitate ${ }^{28}$. Faţă de obiectul prezentului studiu, relevăm riscul gestionării cu dificultate a programului de lucru raportat la fusul orar la care se raportează telesalariaţii, angajatorii şi, eventual, clienţii deserviţi de către aceştia. Pe acest fond, uneori prin forţa împrejurărilor, telesalariatul este în situaţia de a efectua muncă de noapte, aspect care atrage incidenţa dispoziţiilor imperative protective regăsite în art. 125-128 din Codul muncii.

3.6. Suplimentar, apreciem că se impune reglementarea dreptului la deconectare (,R2D”), după modelul altor state membre ale UE (Franţa, Belgia, Spania, Italia $)^{29} . \mathrm{Cu}$ privire la acesta, la nivel european există o preocupare mai

27 Observăm că, din această perspectivă, dreptul intern impune un standard de protecție mai ridicat decât cel reglementat de Directiva 2003/88/CE (care stabilește că orice lucrător trebuie să beneficieze de o perioadă minimă de repaus zilnic de 11 ore consecutive în decursul unei perioade de 24 de ore (art. 3) și, în decursul unei perioade de șapte zile, de o perioadă minimă de repaus neîntrerupt de 24 de ore, la care se adaugă cele 11 ore de repaus zilnic (art. 5)).

28 Aspect care poate pune probleme și în privința identificării lex contractus și/sau lex fori, după caz.

${ }^{29}$ Pentru detalii privind R2D, a se vedea, spre exemplu, O. Vargas-Llave et al., Right to disconnect in the 27 EU Member States, Eurofound Working Paper, 2020, [Online] la https://www.eurofound.europa.eu/sites/default/files/ wpef20019.pdf, accesat 29.09.2021; T. Weber, Right to disconnect: Exploring company practices, Eurofound Research Report, 2021, [Online] la https://www.eurofound.europa.eu/sites/ default/files/ef_publication/field_ef_ document/ef21049en.pdf, accesat 29.09.2021. 
veche, concretizată într-o propunere de directivă $\breve{~}^{30}$ care, în esenţă, vizează cerinţele minime care să le permită lucrătorilor care utilizează instrumente digitale, inclusiv TIC, în scopuri profesionale, să îşi exercite dreptul de a se deconecta şi să garanteze că angajatorii respectă acest drept.

Dreptul la deconectare ar presupune, în esenţă, dreptul de a nu se implica în activităţi sau comunicări legate de activitatea profesională prin intermediul unor instrumente digitale, direct sau indirect, în afara timpului de lucru. În sensul propunerii de directivă, statele membre vor trebui să se asigure că angajatorii instituie un sistem obiectiv, fiabil şi accesibil care să permită măsurarea duratei timpului de lucru zilnic al fiecărui lucrător, în conformitate cu dreptul lucrătorilor la viaţă privată şi la protecţia datelor lor cu caracter personal.

În privinţa măsurilor concrete de punere în aplicare a dreptului de a se deconecta statele membre ar trebui să reglementeze o serie de aspecte importante, printre care:

(a) modalităţile practice de închidere a instrumentelor digitale folosite în scopuri profesionale, inclusiv a oricărui tip de instrumente de monitorizare în scopuri profesionale;

(b) sistemul de măsurare a timpului de lucru;

(c) evaluări în materie de sănătate şi securitate, inclusiv evaluări ale riscurilor psihosociale, legate de dreptul de a se deconecta;

(d) criteriile pe baza cărora se acordă angajatorilor orice derogare de la obligaţia de a pune în aplicare dreptul lucrătorilor de a se deconecta.

În sfârşit, apreciem că reglementarea dreptului la deconectare nu exclude posibilitatea de a se efectua ore suplimentare, în condiţiile legii. Munca suplimentară poate fi programată prin acordul scris al părţilor având astfel caracter previzibil. În acest mod, propunerea angajatorului nu poate interveni intempestiv, cu risc de afectare a calităţii timpului de repaus al telesalariatului.

\section{Consideraţii finale}

Prin adoptarea Legii nr. 81/2018 s-a făcut un prim pas important pentru adaptarea cadrului normativ la evoluţia raporturilor de muncă în cadrul cărora sunt utilizate tehnologii moderne de comunicare la distanţă. Înainte de debutul pandemiei, riscurile păreau mai mult teoretice, iar fenomenul avea oricum o dimensiune redusă în România comparativ cu alte state europene ${ }^{31}$.

${ }^{30}$ A se vedea Rezoluția Parlamentului European din 21 ianuarie 2021 conținând recomandări adresate Comisiei privind dreptul de a se deconecta (2019/2181(INL)), [Online] la https:/www.europarl.europa.eu/doceo/document/TA-9-2021-0021_RO.html, accesat 29.09.2021.

${ }^{31}$ A se vedea, spre exemplu, Eurostat, Working from home in the EU, publicat la 20.06.2018, [Online] la https://ec.europa.eu/eurostat /web/products-eurostat-news/-/DDN20180620-1, accesat 29.09.2021. Conform acestui material, în anul 2018 doar 0,4\% din lucrătorii din România lucrau în mod obișnuit de la domiciliu, media la nivelul UE fiind de 5,7\%. Chiar dacă pandemia COVID-19 a determinat o creștere semnificativă a acestui procent, acesta a rămas totuși foarte redus comparativ cu evoluția mediei la nivelul UE. 
Se poate considera că aspectele pozitive sunt mai pregnante când acest tip de activitate este agreat de părţi fără constrângeri, în aceste situaţii salariatul având şi un capital de negociere mai consistent. Pe acest fond, prin adoptarea legii, România s-a alăturat statelor care au abordat reglementarea telemuncii având în vedere mai degrabă avantajele pe care aceasta în mod potenţial le implică, în special din perspectiva echilibrului între profesie şi viaţa privată (alături de Germania, Polonia, Portugalia, Lituania, Malta ş.a.) $)^{32}$.

Prin raportare la această finalitate, trebuie subliniat că şi Directiva 2019/1158 privind echilibrul dintre viaţa profesională şi cea privată a părinţilor şi îngrijitorilor şi de abrogare a Directivei 2010/18/UE a Consiliului ${ }^{33}$ are în vedere utilizarea unor formule de muncă la distanţă, acolo unde este posibil, ca soluţie pentru ca lucrătorii care sunt părinţi şi îngrijitoriii ${ }^{34}$ să poată să-şi adapteze programul de muncă în funcţie de necesităţile şi preferinţele personale şi, astfel, să rămână în câmpul muncii. În acest context este aşteptată completarea cadrului normativ intern, inclusiv a Legii nr. 81/2018, în procesul de transpunere atât a acestei directive, cât şi a Directivei 2019/1152 privind transparenţa şi previzibilitatea condiţiilor de muncă în Uniunea Europeană ${ }^{35}$, de asemenea relevantă pentru raporturile de muncă la distanţă.

În prezent se poate observa că problematica atrasă de telemuncă este una mai vastă decât a prevăzut legiuitorul în anul 2018. Criza pandemică a forţat într-o anumită măsură desfăşurarea de activităţi de la distanţă ca soluţie de răspuns şi de compromis faţă de perspectiva răspândirii SARS COV2 şi faţă de riscul pierderii locurilor de muncă.

Timpul de muncă la distanţă prezintă unele valenţe diferite după cum acest tip de activitate se desfăşoară conjunctural, în context de criză, sau independent de diverşi factori constrângători.

Astfel, dacă apelul la telemuncă intervine ca soluţie temporară pentru salvarea locurilor de muncă pe fond de diminuare a activităţii angajatorilor, cu sau fără reducerea programului, părţile ar putea beneficia de flexibilitate crescută (inclusiv prin prisma programului de lucru), iar îndeplinirea sarcinilor de serviciu nu va presupune o intensitate crescută determinată de modificarea locului muncii. Dacă, dimpotrivă, ca reacţie la schimbările din mediul economic, unele domenii sunt mutate în mediul virtual, accelerându-se procesul de digitalizare (spre exemplu segmentul distribuţiei de produse, unele servicii), activitatea telesalariaţilor ar putea fi mai intensă, fie ca urmare a elementelor de noutate sau necesităţii

${ }^{32}$ A se vedea și European Agency for Safety and Health at Work, Regulating telework in a post-COVID-19 Europe (2021), [Online] la https://euagenda.eu/upload/publications/ telework--20post-covid.pdf, p. 12, accesat 29.09.2021.

33 Termen de conformare: 2 august 2022.

${ }^{34}$ Conform art. 3 alin. (1) lit. d)din directiva menționată, prin „îngrijitor” se înțelege un lucrător care oferă îngrijire sau sprijin personal unei rude sau unei persoane care locuiește în aceeași gospodărie cu lucrătorul și care are nevoie de îngrijire sau sprijin semnificativ ca urmare a unei probleme medicale grave, astfel cum este definită de fiecare stat membru.

35 Termen de transpunere: 1 august 2022. 
de competenţe digitale crescute cu care se confruntă, fie pentru că activitatea angajatorilor suportă modificări şi/sau are un trend ascendent.

Independent de efectele prin prisma intensităţii muncii, telemunca având caracter parţial forţat de situaţia de criză economică, mediul familial al telesalariaţilor nu mai poate fi privit în mod necesar ca un avantaj, fiind posibil ca mediul de lucru de acasă să nu fie adecvat (spaţiu insuficient sau impropriu, resimţirea unor servituţi care ţin de viaţa personală etc.). De asemenea, riscul unui conflict între viaţa profesională şi viaţa personală poate fi apreciat ca fiind mai ridicat în cazul telemuncii neplanificate, ad hoc.

$\mathrm{Cu}$ toate aceste variabile şi riscuri, telemunca a constituit şi constituie o experienţă pozitivă şi o soluţie viabilă în timpul crizei COVID pentru ambele părţi, salariaţi şi angajatori, fiind dezirabilă în multe situaţii şi în perspectivă postpandemică $\breve{a}^{36}$.

Ne preocupă în mod deosebit, din perspectiva timpului de muncă, specificul telemuncii atunci când aceasta este o opţiune realizată fără constrângeri exterioare prin mijloace electronice de comunicare la distanţă.

În Rezoluţia Parlamentului European din 21 ianuarie 2021 conţinând recomandări adresate Comisiei privind dreptul de a se deconecta (2019/2181(INL)) se face referire la „apariţia unei culturi de a fi „conectat în permanenţă”, „mereu online” sau „mereu de serviciu”, care poate influenţa negativ drepturile fundamentale ale lucrătorilor şi condiţiile de muncă echitabile, inclusiv remunerarea echitabilă, limitarea timpului de lucru, echilibrul dintre viaţa profesională şi cea privată, sănătatea fizică şi mentală, securitatea în muncă”. În mod deosebit se subliniază intensificarea muncii şi prelungirea programului de lucru, estompând astfel limitele dintre viaţa profesională şi cea privată. Din această perspectivă, sunt indicate cercetări Eurofound din care rezultă că $27 \%$ dintre respondenţii care lucrează de acasă au declarat că au lucrat în timpul liber pentru a îndeplini sarcini profesionale şi că există o probabilitate de peste două ori mai mare ca persoanele care lucrează în mod obişnuit de acasă să lucreze în plus faţă de cele 48 de ore săptămânale prevăzute şi să se odihnească mai puţin de cele 11 ore prevăzute între zilele lucrătoare.

Alte studii indică faptul că mai puţin de $60 \%$ dintre lucrătorii la distanţăa atât bărbaţi, cât şi femei, lucrează la „orele obişnuite”, faţă de aproximativ $80 \%$ dintre lucrătorii comparabili care desfăşoară activităţi la locurile de muncă organizate de către angajatori ${ }^{37}$.

Pe de altă parte, s-a apreciat că deşi, în general, telesalariaţii par să lucreze „ore mai lungi” şi mai mult suplimentar faţă de cei care desfăşoară activităţi la locul de muncă organizat de angajator, totuşi, această concluzie nu se verifică în cazul în

${ }^{36}$ Pentru statistici în acest sens, a se vedea D. Ahrendt et. al., Living, working and COVID-19, Eurofound Research Report, 2020, [Online] la https://www.eurofound. europa.eu/ sites/default/files/ef_publication/field_ef_document/ ef20059en.pdf, accesat 29.09.2021.

${ }^{37}$ J.I. Giménez-Nadal, J.A. Molina, J. Velilla, Telework, the Timing of Work, and Instantaneous Well-Being: Evidence from Time Use Data, publicat în ianuarie 2018, [Online] la https://ftp.iza.org/dp11271.pdf, accesat 29.09.2021. 
care sunt comparaţi cu acei salariaţi care nu lucrează de la distanţă, dar li s-a oferit această alternativă şi au refuzat-o. Drept urmare, s-a sugerat că nu telemunca în sine este „responsabilă” pentru durata sau intensitatea muncii, ci mai curând natura postului şi/sau condiţiile impuse de angajator pentru activitatea care poate fi prestată şi de la distanţă (în special sistemul de remunerare axat mai puţin pe recompensarea timpului suplimentar şi mai mult pe acordarea de bonusuri pentru atingerea unor obiective de performanţă). S-a mai apreciat, pe cale de consecinţă, că nu există motive pentru a se presupune că munca la domiciliu va duce automat la intensificarea muncii şi la mai multe ore suplimentare ${ }^{38}$.

După cum se poate observa, analiza timpului de muncă la distanţă poate urma parametri diverşi: natura postului şi a activităţii, predispoziţia sau nevoia de a lucra suplimentar, percepţia asupra timpului, lucrul în cadrul programului obişnuit sau în afara acestuia, timpul de desfăşurare a unei activităţi în mod efectiv sau timp la dispoziţia angajatorului ş.a.

Se poate afirma cu grad ridicat de certitudine că telemunca este potenţată de dezvoltările tehnologice şi potenţează forme contractuale de tip on call sau platform work. S-a arătat şi că munca la domiciliu produce efecte asupra organizării muncii, asupra duratei şi predictibilităţii programului de lucru, conducând la estomparea graniţelor dintre timpul de muncă şi cel de repaus ${ }^{39}$.

Lucrul de la distanţă mai poate determina o tendinţă de depersonalizare a relaţiei telesalariat - angajator, lipsa percepţiei acurate a eforturilor salariatului din timpul programului de lucru, cu potenţiale efecte în sensul supranormării sau a concentrării pe rezultatul activităţii, uneori cu ignorarea perioadelor în care salariatul este la dispoziţia angajatorului/clienţilor acestuia.

Intr-un alt plan, acest tip de activitate poate fie să crească nivelul de armonie dintre viaţa profesională şi cea privată, fie, dimpotrivă, să conducă la instabilitate sau la accentuarea unor dezechilibre latente sau minore. Conştientizarea potenţialelor avantaje şi riscuri, respectarea timpului de muncă şi de odihnă, trebuie să constituie în egală măsură preocupări ale telesalariaţilor.

Pe acest fond, în mod special, aspectele privind programul de lucru, evidenţa, monitorizarea timpului de lucru şi dreptul la deconectare trebuie să fie avute în vedere prin reglementări protective care să nu se limiteze la a lăsa aceste aspecte la dispoziţia părţilor (mai ales în condiţiile în care, în perioade de criză, vulnerabilitatea salariaţilor este mai ridicată şi, pe cale de consecinţă, consimţământul acestora mai uşor de obţinut).

În mod special mijloacele de evidenţă a muncii trebuie să exprime nivelul de tehnologizare a muncii, iar sancţiunile aplicabile în caz de nerespectare a standardelor minimale privind timpul de muncă trebuie să fie eficiente, disuasive.

${ }^{38}$ P. Peters, C. Wetzels, K. Tijdens, Telework: Timesaving or Time-Consuming? An Investigation onto Actual Working Hours, The Journal of Interdisciplinary Economics, 2008, Vol. 19, pp. 421-442.

39 In acest sens și Raportul OIM, Ensuring decent working time for the future, cit. supra. 


\section{Referințe}

Ahrendt D.et. al., Living, working and COVID-19, Eurofound Research Report, 2020

Cioriciu Ştefănescu A., Telemunca, în Revista Română de Dreptul Muncii, nr. 1/2009

Dima L., Aspecte de noutate privind mijloacele materiale de probă în contextul noilor tehnologii, în Conferinţa Internaţională de Dreptul Muncii - Noile tehnologii, consecinţe asupra raportului de muncă, Sibiu, 11-12 octombrie 2019, Editura Universul Juridic, București, 2020

Eurostat, Working from home in the EU, publicat la 20.06.2018

European Agency for Safety and Health at Work, Regulating telework in a post-COVID-19 Europe (2021)

Gheorghe M., Munca prestată prin utilizarea platformelor digitale. Consecinţe asupra principiului egalităţii de tratament, în Conferinţa Internaţională de Dreptul Muncii - Noile tehnologii consecinţe asupra raportului de muncă, Sibiu, 11-12 octombrie 2019, Editura Universul Juridic, București, 2020

Giménez-Nadal J.I., Molina J.A., Velilla J., Telework, the Timing of Work, and Instantaneous Well-Being: Evidence from Time Use Data, publicat în ianuarie 2018, http://dx.doi.org/10.2139/ssrn.3111144

Marica M.E., Contracte de muncă atipice, Editura Universul Juridic, Bucureşti, 2019

Moarcăş C.A., Efectele globalizării, transformarea relaţiei de muncă şi regândirea dialogului social, în Revista Română de Drept Privat, nr. 4/2019

Nenu C.C., Evoluţia conceptului de securitate şi sănătate în muncă în contextul noilor tehnologii, în Conferinţa Internaţională de Dreptul Muncii Noile tehnologii consecinţe asupra raportului de muncă, Sibiu, 11-12 octombrie 2019, Editura Universul Juridic, Bucureşti, 2020

Panainte S., Consideraţii privind alienarea salariatului în industria 4.0., în Conferinţa Internaţională de Dreptul Muncii - Noile tehnologii consecinţe asupra raportului de muncă, Sibiu, 11-12 octombrie 2019, Editura Universul Juridic, București, 2020

Peters P., Wetzels C., Tijdens K., Telework: Timesaving or Time-Consuming? An Investigation onto Actual Working Hours, The Journal of Interdisciplinary Economics, 2008, Vol. 19, https://doi.org/10.1177\%2F02601079X08001900407

Raportul Eurofound, Telework in the European Union, publicat la 10.01.2010

Raportul OIM, Ensuring decent working time for the future, International Labour Conference, 107th Session, 2018, General Survey concerning working-time instruments, Geneva, 2018, Report of the Committee of Experts on the Application of Conventions and Recommendations (articles 19, 22 and 35 of the Constitution), Report III (Part B)

Rezoluţia Parlamentului European din 21 ianuarie 2021 conţinând recomandări adresate Comisiei privind dreptul de a se deconecta (2019/2181(INL))

Samek Lodovici M. et al., The impact of teleworking and digital work on workers and society. Special focus on surveillance and monitoring, as well as on mental health of workers, 2021, publication for the Committee on Employment and Social Affairs, Policy Department for Economic, Scientific and Quality of Life Policies, European Parliament

Servais J.M., Economia colaborativă a platformelor electronice: noi provocări, noi protecţii, în Conferinţa Internaţională de Dreptul Muncii - Noile tehnologii consecinţe asupra raportului de muncă, Sibiu, 11-12 octombrie 2019, Editura Universul Juridic, Bucureşti, 2020

Ştefănescu A., Munca la domiciliu şi telemunca. Drept intern şi comparat, Editura Universul Juridic, București, 2011 
Ţichindelean M., Consideraţii privind protecţia datelor cu caracter personal în raporturile de muncă prin utilizarea mijloacelor de supraveghere video, în Conferinţa Internaţională de Dreptul Muncii - Noile tehnologii consecinţe asupra raportului de muncă, Sibiu, 11-12 octombrie 2019, Editura Universul Juridic, București, 2020

Vargas-Llave O. et al., Right to disconnect in the 27 EU Member States, Eurofound Working Paper, 2020

Weber T., Right to disconnect: Exploring company practices, Eurofound Research Report, 2021 
